\title{
Characteristics of COVID-19 Pneumonia Cases Treated with Favipiravir in the Chest Diseases Clinic
}

\section{Göğüs Hastalıkları Kliniğinde Favipiravir Kullandığımız COVID-19 Pnömonisi Olgularımızın Özellikleri}

\author{
Ali Kadri ÇIRAK $\odot$, Burçin HAKOĞLU $\odot$, Gülru POlat $\odot$, Yelda VAROL $\odot$, Aysu AYRANCI $\odot$ \\ Gülistan KARADENiz ${ }^{\oplus}$, Serir ÖZKAN ${ }^{\oplus}$, Aydan MERTOĞLU ${ }^{\oplus}$, Enver YALNIZ ${ }^{\oplus}$, Fevziye TUKSAVUL ${ }^{\odot}$ \\ Celalettin YILMAZ $\odot$
}

Cite as: Çırak AK, Hakanoğlu B, Polat G, Varol Y, Ayrancı A, Karadeniz G, Özkan S, Mertoğlu A, Yalnız E, Tuksavul F, Yılmaz C. Characteristics of COVID-19 pneumonia cases treated with favipiravir in the chest diseases clinic. İzmir Göğüs Hastanesi Dergisi. 2021;35(2):75-81.

\begin{abstract}
Objective: There is currently no specific treatment for COVID-19. Favipiravir treatment has been shown to be effective in in-vitro and pre-clinical trials in the treatment of COVID-19. In this study, we aimed to present the characteristics and treatment results of our patients who were hospitalized with the diagnosis of COVID-19 pneumonia and received favipiravir treatment in the chest diseases clinics of our hospital. Method: The database created by the COVID-19 Study Group of our hospital consisting of the data of patients diagnosed with COVID-19 who applied to our hospital between March 11, 2020 and May 15, 2020 was examined. 471 patients enrolled in the database and 412 hospitalized patients were evaluated and included in 38 patients in whom favipiravir was used for treatment in the chest diseases clinic. Treatments, drug doses, initiation time of favipiravir, clinical and radiological responses to treatment were analyzed retrospectively. Fever control, improvement of respiratory failure, improvement in laboratory values, and absence of radiological deterioration were accepted as response criteria to treatment.

Results: It was observed that 30 of 38 patients who were given favipiravir treatment in the chest diseases clinic were successfully discharged. Eight patients whose general condition deteriorated despite favipiravir treatment in the clinic and who had an indication for intensive care were transferred to intensive care. Three of these eight patients died and 5 of them were successfully discharged.

Conclusion: Mortality rate was found to be $7.9 \%$ in COVID-19 cases who received favipiravir treatment in our chest diseases clinic. After the favipiravir treatment started to be used more effectively in our country, it was observed that transfers to intensive care units decreased and mortality decreased. Therefore, although favipiravir is thought to be effective in the treatment of COVID-19 infection, further prospective controlled studies are needed.
\end{abstract}

Keywords: COVID-19, pneumonia, favipiravir

Öz

Amaç: COVID-19 tedavisine yönelik onaylanmış spesifik antiviral tedavi bulunmamaktadır. Daha önce influenza ve ebolavirüse karşı kullanılan favipiravir, nükleik asit analoğu ve ribonukleik asit (RNA) bağımlı RNA polimeraz inhibitörü bir ön ilaç olarak, COVID-19 enfeksiyonunda önerilen antiviral tedavi seçenekleri arasındadır. Göğüs hastalıkları kliniklerimizde, tedavisinde favipiravir kullandığımız COVID-19 pnömonili olguları demografik, klinik ve radyolojik özelliklerine göre incelemeyi, tedavi yanıtlarını değerlendirmeyi amaçladık.

Yöntem: Hastanemiz COVID-19 Çalışma Grubu tarafından 11 Mart 2020-15 Mayıs 2020 tarihleri arasında hastanemize bașvuran COVID-19 tanılı hastaların verilerinden olușturulmuș olan veri tabanı incelendi. Veri tabanına kayıtlı 471 hasta içinden yatarak tedavi alan 412 hastanın verileri değerlendirildi ve göğüs hastalıkları kliniğinde tedavide favipiravir kullanılan 38 olgunun klinik takipleri sırasında aldıkları tedaviler, ilaç dozları, favipiravir başlanma zamanı, tedaviye klinik ve radyolojik yanıtları retrospektif olarak incelendi. Ateş kontrolü, varsa solunum yetmezliğinin düzelmesi, laboratuvar değerlerindeki iyileșme, radyolojik kötülessme olmaması tedaviye yanıt kriterleri olarak kabul edildi.

Bulgular: Göğüs hastalıkları servisinde favipiravir tedavisi verilen 38 hastanın 30'unun başarıyla taburcu edildiği görüldü. Serviste yatarken favipiravir başlanmasına rağmen genel durumu bozulan ve yoğun bakım endikasyonu doğan 8 hastanın yoğun bakıma nakli yapıldı. Bu 8 hastanın 3'ü vefat etti ve 5'i başarılya taburcu edildi.

Sonuç: Çalışmamızda göğüs hastalıkları kliniğinde favipiravir tedavisi alan COVID-19 olgularında mortalite oranı \%7.9 olarak bulunmuştur. Favipiravir tedavisinin ülkemizde daha etkin bir şekilde kullanılmaya başlanmasının ardından yoğun bakım nakillerinin azaldığı ve mortalitenin düştüğü gözlenmiştir. Bu nedenle favipiravirin COVID-19 enfeksiyonun tedavisinde etkin olduğu düşünülmekle birlikte ileri prospektif kontrollü çalışmalara ihtiyaç vardır.

Anahtar kelimeler: COVID-19, pnömoni, favipiravir
Received/Gelis: 02.02 .2021

Accepted/Kabul: 01.05.2021

Published Online/Online Yayın: 06.08.2021

Corresponding author/Sorumlu yazar:

A. K. Cirak

ORCID: 0000-0002-0137-1124

T.C. Sağlık Bakanlığı SBÜ İzmir Dr. Suat Seren Göğüs Hastalıkları ve Cerrahisi SUAM İzmir - Türkiye

alikadri.cirak@saglik.gov.tr

B. Hakoğlu

ORCID: 0000-0002-41 79-1828

G. Polat

ORCID: 0000-0002-2211-1268

Y. Varol

ORCID: 0000-0003-4604-7173

G. Karadeniz

ORCID: 0000-0002-1994-6723

S. Özkan

ORCID: 0000-0001-5460-8300

A. Mertoğlu

ORCID: 0000-0003-4019-3647

E. Yalnız

ORCID: 0000-0002-3231-9513

E. Tuksavul

ORCID: 0000-0002-4133-2074

C. Yilmaz

ORCID: 0000-0002-8426-0680

T.C. Sağlık Bakanlığı SBÜ İzmir Dr. Suat Seren Göğüs Hastalıkları ve Cerrahisi SUAM

İzmir - Türkiye

A. Ayranci

ORCID: 0000-0002-8939-336X T.C. Sağlık Bakanlığı İzmir

II Sağlık Müdürlüğü Bakırçay Üniversitesi Çiğli Eğitim ve Araştırma Hastanesi

Izmir - Türkiye

${ }^{\S}$ Bu çalışma Türk Toraks Derneği'nin 23. Yıllık Kongresi etkinliğinde 15.10.2020 tarihinde sözlü bildiri olarak sunulmuştur.

(C) Telif hakkı İzmir Göğüs Hastanesi'ne aittir. Logos Tıp Yayıncllık tarafından yayınlanmaktadır.

Bu dergide yayınlanan bütün makaleler Creative Commons 4.0 Uluslararası Lisansı (CC BY) ile lisanslanmıștır. 


\section{INTRODUCTION}

The first coronavirus disease-2019 (COVID-19) case in our country was diagnosed on March 11 th 2020, on the same date when World Health Organization (WHO) announced COVID-19 outbreak a pandemic.

A major part of the cases with severe acute respiratory syndrome coronavirus-2 (SARSCoV-2) infection which may affect people of any age group has a mild-moderate clinical course, and in approximately 5\%-10\% of the patients the severity of the clinical course is at a lifethreatening level. Therefore, an efficacious specific treatment is urgently needed ${ }^{(1,2)}$. On the other hand, there is still not a specific proven treatment for COVID-19. Favipiravir (T-705; 6-fluoro-3-hydroxy-2- pyrazinecarboxamide) is an antiviral agent with a selective action on ribunucleic acid-dependent ribonucleic acid polymerase (RdRp) ${ }^{(3)}$. It has been effectively used in the treatment of influenza and ebola virus and has been shown to be effective in the treatment of COVID-19 in-vitro and in preclinical experiments ${ }^{(3-5)}$.

Patient management of COVID-19 in our country is carried out in accordance with the guidelines prepared by the Scientific Committee of the Ministry of Health. While initial guidelines recommend starting favipiravir treatment in cases of pneumonia that do not respond to hydroxychloroquine treatment or very severe pneumonia, today it forms the basis of favipiravir treatment in all COVID-19 cases ${ }^{(6)}$. It was aimed in this study to present the characteristics and treatment outcomes of our cases who received favipiravir treatment with the diagnosis of COVID-19 in the chest diseases clinics of our hospital.

\section{MATERIALS and METHODS}

\section{Subjects and Study Design}

The data of 471 cases diagnosed with COVID19 and treated in the chest diseases clinics of our hospital between 11 March 2020 and 15 May 2020 were retrospectively analyzed (consent of the scientific committee of our hospital and Ministry of Health COVID-19 Scientific Research Evaluation Committee date/number 05.21.2020/4352). Thirty eight patients who received favipiravir treatment were evaluated. Clinical severity of the patients was determined by using the disease severity classification of the Ministry of Health. In accordance with this, criteria of severe pneumonia are dyspnea, tachypnea ( $\geq 30 / \mathrm{min}$ ), $\mathrm{O}_{2}$ saturation $<90 \%$ or bilateral diffuse involvement in pulmonary imaging ${ }^{(6)}$. The radiological and laboratory values and comorbidities of all the patients were recorded. Treatments received during follow up, drug doses, time onset of favipiravir, clinical and radiological responses to treatment were recorded. Fever control, improvement of respiratory failure (if present), improvement in laboratory values, absence of radiological progression are regarded as criteria of response to treatment. Indications for prescribing favipiravir and dosages were determined according to the guidelines of the Ministry of Health Scientific Committee (Figure 1) ${ }^{(6)}$.

\section{Statistical Analysis}

SPSS for Windows ${ }^{\circledR} 25.0$ was used for statistical analyses. Descriptive statistics were expressed as mean \pm standard deviation or median for continuous variables.

\section{RESULTS}

Among the 38 who received favipiravir treat- 


\begin{tabular}{|c|c|c|}
\hline \multicolumn{3}{|c|}{ Treatment in Probable/Definite COVID-19 Cases with Severe Pneumonia*** } \\
\hline $\begin{array}{l}\text { Hydroxychloroquine }^{2} \\
200 \text { mg tablet } \\
\text { AND/ OR } \\
\text { Favipiravir }^{1} \\
200 \mathrm{mg}^{2} \text { tablet }\end{array}$ & $\begin{array}{l}\text { 2x1600 mg loading dose, } \\
2 \times 600 \text { mg maintenance dose }\end{array}$ & 5 days \\
\hline \multicolumn{3}{|c|}{$\begin{array}{l}\text { Treatment in cases with worsening of clinical symptoms while } \\
\text { hydroxychloroquine or with progressive pneumonia signs }\end{array}$} \\
\hline $\begin{array}{l}\text { Favipiravir }{ }^{1} \\
200 \mathrm{mg}^{2} \text { tablet }\end{array}$ & $\begin{array}{l}2 \times 1600 \text { mg loading dose, } \\
2 \times 600 \text { mg maintenance dose }\end{array}$ & 5 days \\
\hline
\end{tabular}

Figure 1. Treatment recommendations in COVID-19 cases with indication for hospitalization according to ministry of health COVID-19 scientific committee guidelines

Table 1. The distribution of the comorbidities.

\begin{tabular}{ll}
\hline Comorbidity & n (\%) \\
\hline HT & $8(21)$ \\
DM & $3(7)$ \\
Cardiac disease & $1(2)$ \\
COPD/Asthma & $1(2)$ \\
Malignancy & $2(4)$ \\
Multiple & $5(13)$ \\
\hline
\end{tabular}

Table 2. The distribution of symptoms according to Frequency.

\begin{tabular}{lr}
\hline Symptom & n (\%) \\
\hline High fever and cough & $24(63)$ \\
Shortness of breath & $18(47)$ \\
Myalgia & $8(21)$ \\
Anorexia & $7(18)$ \\
Nausea-vomiting & $5(13)$ \\
\hline
\end{tabular}

${ }^{*} H T$ : hypertension, DM: diabetes mellitus, COPD: chronic obstructive pulmonary disease

Table 3. Laboratory results of the cases treated with favipravir in hospital.

\begin{tabular}{lccc}
\hline & Normal & Mean & S. deviation \\
\hline Lymphocytes $\left(10^{3} / \mathrm{uL}\right)$ & $1200-3500$ & 1057.8 & 442.1 \\
LDH $(\mathrm{U} / \mathrm{L})$ & $<225$ & 309.4 & 170.9 \\
Ferritin $(\mathrm{ng} / \mathrm{mL})$ & $<150$ & 706.5 & 696 \\
D-dimer $(\mathrm{ng} / \mathrm{mL})$ & $<500$ for $\leq 50$ years & 1775 & 2353 \\
Troponin $(\mu \mathrm{g} / \mathrm{L})$ & 10 age for $>50$ years & $0-14$ & 3.7 \\
\hline
\end{tabular}

${ }^{*} \mathrm{LDH}$ : lactate dehydrogenase

ment in the service, 21 of them (55\%) were male and the median age was 54 years (25-74). Twenty patients were current smokers and the median cigarette consumption was 15 packs-year (5-100). Four patients were ex-smokers and 14 patients had never smoked. Eighteen patients (43\%) had no comorbidities. While 5 patients only had hypertension, 6 patients had two or more comor- bidities (Table 1). Hypertension was one of the comorbidities in 3 of the patients with more than one comorbidity. Two patients had an accompanying malignancy.

Thirty-one cases had been diagnosed with COVID-19 with a polymerase chain reaction (PCR) test performed using oronasal smear samples. In 3 cases with negative PCR tests performed on 3 
consecutive smear samples, rapid antibody test yielded positive results. Four patients were accepted clinically and radiologically as COVID19 and treatment was given.

Fever and cough were present in 24 cases (63\%) at the time of presentation. Symptom durations ranged between 2 days to 11 days. The distribution of symptoms according to frequency is given in Table 2 .

Physical examination revealed a mean axillary fever of 37.9 (SD: 1.3) degrees and a mean breathing rate of 19 (SD: 1.9). Two patients were hypertensive at the time of presentation and the others were normotensive. The mean oxygen saturation measured with pulse oxymetry at the time of admission was $97.4 \%$ (SD:4.7).

The laboratory results are presented in Table 3.

Chest X-rays of the patients revealed diffuse heterogenous density increases in 13 patients, and these were in the mid-inferior zones in 10 and only in the inferior zones in 9 patients; chest X-rays were normal in 6 patients but a clinical diagnosis of pneumonia was made.

Thoracic high resolution computerized tomography (HRCT) imaging was performed in 35 patients at presentation. Bilateral ground glass opacities were detected most frequently in HRCT (Table 4).

When the patients were evaluated regarding

Table 4. Thoracic high resolution computerized tomography findings.

\begin{tabular}{ll}
\hline Radiological pattern & n (\%) \\
\hline Bilateral ground glass & $32(84)$ \\
Ground glass + consolidation & $12(32)$ \\
Parenchymal nodule & $10(26)$ \\
$\quad$ solid & 5 \\
$\quad$ semi-solid & 3 \\
$\quad$ pure ground glass & 2 \\
Reverse halo & $5(13)$ \\
Spider web & $5(13)$ \\
Pleural effusion & $2(5)$ \\
Crazy paving & $1(2.6)$ \\
\hline
\end{tabular}

treatment, it was seen that all patients received hydroxychloroquine in compliance with the guidelines. Thirty-three patients received low molecular weight heparin (LMWH) treatment at therapeutic or prophylactic doses. Twenty-four patients needed oxygen support at 1-3 lt/min during treatment.

Fifteen patients had previously completed treatment with hydroxychloroquine and favipiravir treatment was initiated when they presented due to clinical-radiological deterioration (persistent fever, persistent dyspnea). And 23 patients who showed clinical, laboratory and radiological worsening on the 2nd-9th days of hydroxychloroquine treatment while hospitalized in our clinics were started on favipiravir treatment. As recommended in the guidelines of the Ministry of Health, favipiravir was given at a loading dose of $2 \times 1600 \mathrm{mg}$ on the first day, followed by $2 \times 600$ mg maintenance dose for 4 days.

Nausea, vomiting and gastric irritation were seen in 3 patients, and mild elevations in liver function tests were seen on the third day of treatment in 1 patient. Adverse events were controlled with supportive therapy. None of the adverse effects required cessation of the favipravir.

When the success of the treatment was evaluated, it was noted that 30 patients who were started on favipiravir treatment due to clinical and radiological deterioration were discharged successfully (\%79). Eight patients whose general condition deteriorated despite favipiravir treatment were transferred to the intensive care unit (ICU). Three of these 8 patients died and 5 were discharged with success. The mortality rate after transfer to the ICU of the patients who received favipiravir treatment was $7.9 \%$. No death was observed in the chest diseases clinic in any of the patients who received favipiravir treatment. Two of these 3 patients who died in the ICU were 
diagnosed with known bronchial carcinoma, the other was a patient with a diagnosis of atherosclerotic heart disease and high levels of $\mathrm{LDH}$, ferritin, and D-dimer. The other 5 patients who did not result in death, LDH, D-dimer, and ferritin levels had elevated and there was no accompanying comorbidity. Survival was $92.1 \%$ in patients who received favipiravir treatment.

\section{DISCUSSION}

The COVID-19 pandemic is a serious social problem that has caused many deaths all over the world and has no specific treatment yet. Favipiravir treatment has been and continues to be used as the most promising drug in the treatment of COVID-19 to date. In this study, need for ICU was $21 \%$ and overall mortality was $7.9 \%$ in 38 patients who received favipiravir treatment in the chest diseases clinic.

Favipiravir is a pro-drug which inhibits RdRp and has been shown to be effective in RNA viruses like influenza and Ebola ${ }^{(5,7)}$. In a study of Wang et al., it was shown to be effective in vitro in the treatment of SARS-CoV-2 infection. It was concluded in this study that favipiravir could be used in COVID-19 infection ${ }^{(8)}$.

One hundred and seventy-nine patients were included in the study of Du et al., and the mean age of the patients was $57.6 \pm 13.7$ years. The mean ages of 21 exitus and 158 surviving cases were $70.2 \pm 7.7$ years and $56.0 \pm 13.5$ years, respectively, and the difference was statistically significant $(p<0.001)^{(9)}$. On the other hand, in the study of Cai et al., the median age of the patients was 43 years (35.5-59) ${ }^{(10)}$. Again in the study of Chen et al., 75\% of the patients were 65 years old or younger ${ }^{(11)}$. Similarly, the median age in our study was $54-55$ years (25-74) which is similar to other studies. All 3 of our patients who died were
64 years old or older.

In studies performed with favipiravir, male gender was found at a rate of $40 \%-50 \%$ and female gender $50 \%-60 \%{ }^{(10,11)}$. In our study, $45 \%$ of our patients were female and $55 \%$ were male.

Regarding comorbidities, the most frequent concomitant diseases in the group receiving favipiravir treatment were hypertension (31\%) and DM (12\%) in the study of Chen et al. ${ }^{(11)}$. In our study, the most frequent comorbidities were also hypertension (21\%) and DM (7\%), similar to the literature.

The most frequent symptom seen in the studies performed on patients receiving favipiravir for the treatment of COVID-19 was fever and this was followed by cough ${ }^{(10,11)}$. Similarly, fever and cough were also the most frequent symptoms in our study, in accordance with the literature.

In a single-arm clinical study performed for the treatment of Ebola in Guinea, favipiravir was used at a loading dose of $6000 \mathrm{mg}$ on the first day followed by a total dose of $1200 \mathrm{mg}$ twice daily for 10 days ${ }^{(5)}$. In the study of Cai et al., favipiravir was administered at a loading dose of $\mathbf{3 2 0 0} \mathbf{m g}$ on the first day followed by a total dose of $1200 \mathrm{mg}$ twice daily for 14 days ${ }^{(10)}$. In our country, in compliance with the guidelines prepared by the Ministry of Health for the treatment of COVID-19, although the dose administered is similar to that in the study of Cai et al., total treatment duration is recommended as 5-10 days ${ }^{(6)}$.

In an open-end controlled study including 80 patients with a confirmed COVID-19 diagnosis, 35 patients received oral favipiravir and 45 patients oral lopinavir/ritonavir together with inhaler interferon (IFN) therapy, and these two groups were compared. The viral clearance time was found to be significantly shorter in the favipiravir group compared with the other group [median (interquartile range IQR), 4 (2.5-9) days 
vs 11 (8-13) days, $p<0.001]$. In addition, a significantly more marked radiological improvement was noted in the favipiravir arm $(91.3 \%$ vs $62.2 \%$, $\mathrm{p}=0.004)^{(10)}$. In the randomized controlled study of Ivashchenko et al., $90 \%$ of the patients who received favipiravir and $80 \%$ of the patients who received standard of care (hydroxychloroquine or chloroquine or lopinavir/ritonavir) showed improvement in thoracic CT findings on the 15th day of treatment ${ }^{(12)}$. In our study, viral clearance was not checked and although it is not a comparative study, a marked clinical and radiological improvement was noted in our patients receiving favipiravir.

In a randomized controlled study comparing patients followed with the diagnosis of mildmoderate COVID-19, 120 patients received favipiravir and 120 patients received arbidol; healing was significantly faster in the study arm receiving favipiravir $(p=0.0199)$. In the same study, the time of fever control and relief in cough was significantly shorter in the favipiravir arm compared with the arbidol arm $(p<0.001)$. But there was no difference in the rates of administering $\mathrm{O}_{2}$ therapy or NIMV (non invasive mechanical ventilation) treatment ( $>>0.05)$ (11). We used favipiravir treatment in patients who developed critical disease as a result of progression during follow up and in those with severe pneumonia and critical disease at the time of presentation, in accordance with the recommendations in the guidelines of the Ministry of Health. And we achieved successful outcomes over ninety percent.

In a study of Cai et al. comparing favipiravir with lopinavir/ritonavir, adverse effects were more frequent in the lopinavir/ritonavir arm. Although rare, the most frequent adverse effects were gastric complaints and impaired liver function tests in the favipiravir arm ${ }^{(10)}$. In the metaanalysis of D. B. Shrestha et al. comparing favipi- ravir with other antiviral drugs, the most frequent advers effects were nausea, vomiting, diarrhea and an increase in transaminases ${ }^{(13)}$. On the other hand, the most frequently seen adverse effects in our study were also nausea and impaired liver function tests, and none of the adverse effects required cessation of the drug.

In the randomized controlled study of Ivashchenko et al. including 60 patients and comparing patients who received favipiravir $1600 \mathrm{mg}$ on day 1 followed by $600 \mathrm{mg}$ on days $2-14$, or favipiravir $1800 \mathrm{mg}$ on day 1 followed by $800 \mathrm{mg}$ on days 2-14, or standard of care according to the Russian guidelines for treatment of COVID19,2 patients $(10 \%)$ in the group receiving favipiravir $(1600 / 600 \mathrm{mg})$ needed an intensive care unit and died ${ }^{(12)}$. While overall mortality rate is $2.5 \%$ in Turkey, this rate can be as high as $4.3 \%$ in the world ${ }^{(14)}$. Mortality rate may increase up to $80 \%$ among patients admitted to the intensive care unit because of disease severity ${ }^{(15)}$. As expected in our study, although mortality rate was higher in severe pneumonia cases receiving favipiravir than the rates in all the cases, it was below the mortality rates occurring in intensive care units.

The main limitation of this study is its retrospective nature and not being a comparative study.

Consequently, mortality rate was found to be 7.9\% in COVID-19 cases who received favipiravir treatment in our chest diseases clinic. However, prospective, controlled studies are needed regarding the efficacy of favipiravir in the treatment of COVID-19.

Ethics Committee Approval: S.B.U. Dr. Approval was obtained from Suat Seren Chest Diseases and Surgery Training and Research Hospital and the Ministry of Health COVID-19 Scientific Research Board (12.06.2020/25). 
Conflict of Interest: There is not any conflict of interest.

Funding: There is no financial support.

Informed Consent: It is a retrospective study.

\section{REFERENCES}

1. Zunyou Wu and McGoogan JM. Characteristics of and important lessons from the coronavirus disease 2019 (COVID-19) outbreak in China: summary of a report of 72.314 cases from the Chinese Center for Disease Control and Prevention. JAMA 323. 2020;13:1239-42. https://doi.org/10.1001/jama.2020.2648

2. Hoffmann C. Treatment. In: Kamps BS, Hoffmann C, eds. Covid Reference, Edition 2020-2. SteinHauser Verlag; Amedeo, Germany; 2020. Website www.covidreference.com [accessed 12 April 2020].

3. Du, Yin-Xiao, and Xiao-Ping Chen. Favipiravir: pharmacokinetics and concerns about clinical trials for 2019nCoV infection. Clinical Pharmacology \& Therapeutics (2020). https://doi.org/10.1002/cpt.1844

4. Kimiyasu $\mathrm{K}$ and Daikoku T. Favipiravir, an anti-influenza drug against life-threatening RNA virus infections. Pharmacology \& Therapeutics 2020:107512. https://doi.org/10.1016/j.pharmthera.2020.107512

5. Daouda $S$, et al. Experimental treatment with favipiravir for Ebola virus disease (the JIKI Trial): a historically controlled, single-arm proof-of-concept trial in Guinea. PLoS medicine 13.3 2016:e1001967. https://doi.org/10.1371/journal.pmed.1002066

6. Ministry of Health (2020). COVID-19 Yeni Koronavirüs Hastalığı [online]. Website: https://covid19bilgi.saglik. gov.tr/ tr/ [accessed 17April 2020].

7. Vincent $M$ et al. Ebola virus dynamics in mice treated with favipiravir. Antiviral Research 2015;123:70-7. https://doi.org/10.1016/j.antiviral.2015.08.015

8. Manli W, et al. Remdesivir and chloroquine effectively inhibit the recently emerged novel coronavirus (2019$\mathrm{nCoV}$ ) in vitro. Cell Research 2020;30(3):269-71. https://doi.org/10.1038/s41422-020-0282-0

9. Rong-Hui D, et al. Predictors of mortality for patients with COVID-19 pneumonia caused by SARS-CoV-2. European Respiratory Journal 56.3 (2020). https://doi.org/10.1183/13993003.00524-2020

10. Qingxian C, et al. Experimental treatment with favipiravir for COVID-19: an open-label control study. Engineering 2020. https://doi.org/10.1016/j.eng.2020.03.007

11. Chang C, et al. Favipiravir versus arbidol for COVID-19: a randomized clinical trial. MedRxiv (2020). https://doi.org/10.1101/2020.03.17.20037432

12. Ivashchenko AA, et al. AVIFAVIR for treatment of patients with moderate COVID-19: interim results of a phase II/III multicenter randomized clinical trial. medRxiv (2020). https://doi.org/10.1093/cid/ciaa1176

13. Shrestha, Dhan Bahadur, et al. "Favipiravir versus other antiviral or standard of care for COVID-19 treatment: a rapid systematic review and meta-analysis." Virology Journal 17.1 2020:1-15. https://doi.org/10.21203/rs.3.rs-40775/v1

14. World Health Organization, WHO Coronavirus Disease (COVID-19) Dashboard, Data last updated: 2020/7/15.

15. CDC COVID-19 Response Team, Severe Outcomes Among Patients with Coronavirus Disease 2019 (COVID19) - United States, February 12-March 16, 2020, MMWR Morb Mortal Wkly Rep. 2020 Mar 27;69(12):343-6. https://doi.org/10.15585/mmwr.mm6912e2 